\title{
Transposition
}

Musique et Sciences Sociales

$4 \mid 2014$

Musique et conflits armés après 1945

\section{Martin Iddon, Music at Darmstadt. Nono, Stockhausen, Cage, and Boulez}

Cambridge, Cambridge University Press, 2013, 349 p.

\section{Annelies Fryberger}

\section{(2) OpenEdition}

\section{Journals}

Édition électronique

URL : http://journals.openedition.org/transposition/504

DOI : 10.4000/transposition.504

ISSN : 2110-6134

Éditeur

CRAL - Centre de recherche sur les arts et le langage

Référence électronique

Annelies Fryberger, " Martin Iddon, Music at Darmstadt. Nono, Stockhausen, Cage, and Boulez »,

Transposition [En ligne], 4 | 2014, mis en ligne le 15 juillet 2014, consulté le 22 septembre 2020. URL:

http://journals.openedition.org/transposition/504 ; DOI : https://doi.org/10.4000/transposition.504

Ce document a été généré automatiquement le 22 septembre 2020.

La revue Transposition est mise à disposition selon les termes de la Licence Creative Commons Attribution - Partage dans les Mêmes Conditions 4.0 International. 


\section{Martin Iddon, Music at Darmstadt. Nono, Stockhausen, Cage, and Boulez}

Cambridge, Cambridge University Press, 2013, 349 p.

Annelies Fryberger

\section{RÉFÉRENCE}

Martin Iddon, Music at Darmstadt. Nono, Stockhausen, Cage, and Boulez, Cambridge, Cambridge University Press, 2013, 349 p.

\section{NOTE DE L'AUTEUR}

The author wishes to thank Nicolò Palazzetti for his insightful comments on this review.

In the best sociological tradition, Martin Iddon uses his limpid prose to show us that things are not what they seem: the serialists were never fully serial, and there is a cavern of critique, interpretation, and analysis separating discourse and practice. The thrust of this richly documented volume is an analysis of the controversy regarding the legacy of Webern within the context of the early years, under Wolfgang Steinecke's direction (1949-1961), of what would become the Internationale Ferienkurse für Neue Musik in Darmstadt. In the end, Iddon shows that Webern would be used to legitimize the rise of serialism; his music became a calling card for the 'school' of multiple serialism which brought together composers who, despite the halo of discourse and founts of critique, only marginally actually fully applied this technique in their own compositions. Iddon convincingly argues that the identity of this fledgling movement crystallized thanks to the controversy surrounding it, with one of the key players being that of Theodor W. Adorno and his scathing critique of the composers involved (notably of Pierre Boulez and Karel Goeyvaerts). This school took hold more thanks to 
the discourse produced about it than to the compositions actually being produced within it.

2 The figure of Adorno is omnipresent in this study, but not as a secondary source rather as an actor with an ideological discourse worthy of careful analysis. As such, the question of authority is an undercurrent throughout the entire book: the question is who controls the discourse on new music and why. This book thus presents a perfect case study for themes developed since the 1990s in the wake of New Musicology: analysis is by no means a neutral process, and authority and value are social constructions. In the preface, Iddon clearly situates his work as "a study of the reception of new music" (p.xi), and his methodology indeed incorporates careful archival work to recreate the critical reception of the music performed and discussed in the early years of Darmstadt, combined with focused analyses of certain key pieces, in order to better understand (or reveal inconsistencies in) the press and academic reception. Iddon purports that the young composers present at the time (notably Pierre Boulez, Luigi Nono, and Karlheinz Stockhausen) were used as pawns in a struggle between Adorno and the critic Herbert Eimert and Heinz-Klaus Metzger (critic and, crucially, translator into German of John Cage's lectures at Darmstadt) regarding the “"proper' course" (p. xii) of new music after World War II. Adorno had high hopes that music analysis might save the new music world from what he qualified as the "crisis" it suffered from at the time ${ }^{1}$, while Eimert and Metzger hoped first and foremost to discredit and dethrone Adorno, largely via a reification of Webern to counter Adorno's view that Webern's "static" techniques would lead inevitably to a stranglehold on the composer's freewill (see p. 92).

3 As an example of how Iddon presents these disputes, and how musical analysis is used to understand the discourse surrounding the works discussed, let us look at how he presents the case of Luigi Nono's Polifonica-Monodia-Ritmica, premiered at Darmstadt on 10 July 1951. Iddon shows how Nono uses Brazilian rhythms (thanks to his interaction with the Brazilian composer Eunice Katunda ${ }^{2}$ ) and Edgar Varèse's "emancipation of percussion" (p. 43) as his primary points of departure for this piece. Procedurally, the material is generated using a permutation of a limited range of rhythmic materials, but this procedure is by no means slavishly adhered to (p. 44). However, Adorno had in some ways prepared the reception for this piece, given that he gave a presentation on the music of Webern some short days before, so critics were primed to see the links between this still, austere piece and the music of Webern (p. 45). This comparison with Webern and twelve-tone compositional techniques was used to elevate Nono's work, and was meant as high praise, despite this interpretation being clearly misplaced upon closer analysis of the score and Nono's declarations. With this example, we see how Iddon tells the tale of the reception of the work of what came to be known as the 'Darmstadt School:' he reveals the gap between the works and the critical discourse surrounding them, and shows how misinterpretation can be used to federate seemingly disparate composers.

The first performance of Webern at Darmstadt was in 1948, with his Variations for piano, op. 27 (1935-1936) (p. 29). In the early years, the Second Viennese School by no means dominated: Hindemith was really the star at the courses' inception ${ }^{3}$. Similarly, the now well-nigh forgotten Belgian composer Karel Goeyvaerts (1923-1993) was the first to truly follow the path of applying 'twelve-tone' treatment to both pitch and rhythm (notably with his Sonata for Two Pianos (1951), and he was really seen as the composer to 
watch in 1951 (p. 61). Indeed, he was credited at the time as being the inventor of what one critic was led to call "a system of "static music" (Albert Rodemann, quoted on p. 85). In investigating these shifts, away from Hindemith and toward a reification of the Second Viennese School (and then subsequent distancing from same), and a more local focus moving from Goeyvaerts to Stockhausen, Iddon shows how what could seem to be at first glance as an example of history doing its work of sifting out the wheat from the chafe is actually much more about power struggles and actors' jostling for position at the crucial time when reputations were still being formed. History's verdict is the result, not just of the passing of time and changing tastes (the trope of the more enlightened future audience), but of how these power struggles turn out in the moment they are being fought - something the actors involved are keenly aware of (see, regarding Goeyvaerts, p. 68).

In several detailed analyses of pieces by Bruno Maderna, Pierre Boulez, Karlheinz Stockhausen, and Luigi Nono, among others, Iddon reveals (one can see him smiling slyly through the text) that these pieces can ontologically, but not phenomenologically, be seen as serialist. Meaning, these pieces derive much of their material from twelvetone or serialist generative processes, but the intervention of the composer in these processes creates a sounding result that cannot be foreseen via these processes alone (see, for example, p. 81). The example of Boulez's Structures Ia (1952) is presented as an aberration - both in the context of Boulez's oeuvre as a whole, and in the context of other 'serial' composers - in that it does present a rigorous adherence to multiple serialism. What unites these composers, in the end,

[...] is little more than existence of pre-compositional work which includes independent consideration of more than one parameter, typically pitch and rhythm (although more than two are, of course, possible). Gottfried Michael Koenig suggested that '[i]n the beginning, one's attention was focused on pitches, durations, intensities, and timbres. Then other qualities or issues became pressing: groups, which consisted of many notes; spatially conceived sound events; new musical instruments or new ways of playing old ones; liberties given to performers; musical action.' Yet even according to such a conservative view, [Maderna and Nono] would have been excluded. [...] What the composers had to say hardly exhibited much unanimity either [...]. Nevertheless, as Boulez would implicitly observe [...], one important unifying characteristic was that the material which was pre-compositionally generated, regardless of whether or not it was followed in a slavish way in the composition proper, led to the structure and form of the piece, rather than being suspended in an extant formal shape (p. 83-84).

6 Considering the weight and influence that the 'Darmstadt school' would have in future discourse and production in new music, this is a remarkably thin thread by which to unite these composers. Iddon gives us a detailed analysis of how these composers' compositional processes were reconstructed and recontextualized in press coverage, leading eventually to their being identified as a unit, despite their differences and the conflicts amongst them (see, regarding Nono: p. 88).

7 An underlying thread in this discussion of how the serialists became serialists is the process of building a consensus around how Webern's music should best be analyzed. In the period under study here, just some short years after Webern's death in 1945, the way his music should be interpreted and what it meant for the future of new music was far from clear. With this discussion, Iddon's volume enters more general territory: that of the politics of musical analysis. The neutrality of musical analysis can no longer be taken for granted, and Iddon is not alone in investigating its possible implications ${ }^{4}$. $\mathrm{He}$ 
analyzes in detail divergent interpretations of the implications of Webern's work by Nono, Stockhausen, Boulez, and Goeyvaerts (with the overarching conflict being that between Eimert and Adorno) presented in the context of a series of lectures on Webern during the summer course in 1953. Just one example of how these interpretations differ can be found in contrasting Boulez and Goeyvaerts: "If, for Goeyvaerts, the idea of generating structure from smaller elements led to an objectivisation of the material, for Boulez it led, instead, to a reflexive, questioning practice" (p. 94). This contrast, among others analyzed by Iddon, was glossed over in the critical reception of these lectures, wherein these four composers were united with Webern as their guide, and the notion of a 'school' was born (pp. 98 and 129). The press would then emphasize the thorough pre-determination in these composers' works, even though examples of this are exceedingly rare (p. 107). What is important to note, however, is that at the time, it was far from clear that Webern should be the overarching figure in this teleological view of the development of new music. Instead, a multiplicity of influences was present: among them, Iddon discusses in detail Schoenberg, Messiaen, Webern, Debussy, and Bartók.

Within a larger discussion of the reception of American new music composers at Darmstadt, the second controversy analyzed in this volume is that of how John Cage's music was received, with the fundamental misunderstanding being: was David Tudor improvising or not? This misunderstanding seems to have been largely due to general ignorance regarding the way Tudor prepared indeterminate scores for performance (p. 249), as reflected, for instance, in Nono's 1959 remarks on Cage (p. 259). Iddon shows that Cage's music was largely misconstrued at Darmstadt as being based on improvisation, with critics misunderstanding the fundamental difference between indeterminacy or chance compositional practices and a score which would call on the interpreter to improvise. This misunderstanding would underlie the critical reception of Cage's music in Darmstadt and beyond.

John Cage made his first appearance on the Darmstadt stage in 1958, and his work was met with what can only be described as confusion, sometimes expressed in curiosity, sometimes in hostility (p. 200-201). He and David Tudor played European premieres of several of Cage's pieces, among them Variations I (1958) and Winter Music (1957). This performance was followed by a series of lectures, wherein Cage endeavored to explain the chance processes he used. He purported that the fundamental difference between European and American composers lay not in the use of serial techniques or chance operations, but rather that "Europeans [...] wanted to be 'composers' through the operations of their wills and compositional desires, and Americans [...] were willing to allow music to occur unpurposively" (p. 215). This is reflected in Boulez's critique of Cage. Boulez felt that Cage, with his chance compositional practices, fundamentally refused to do that which defines a composer: to choose (p. 187). Boulez was sympathetic to controlled chance in the compositional process, but not to performance indeterminacy, where certain choices are left open to the performer (p. 188). In some respects, conflicts regarding Cage led to open conflict in the already divided Darmstadt 'school', notably between Stockhausen and Nono (Stockhausen felt that Nono had defiled the Darmstadt spirit of collegiality in his frontal attack on Cage in 1959 (p. 264), or between Boulez and Stockhausen (with Stockhausen initially embracing Cage, while Boulez was at first highly critical). To a certain degree, the flurry of critique leveled at Cage was a way to air out differences already present among the composers who had been lumped together in the Darmstadt school, and as such allowed them to assert 
their individuality as composers (p. 286). More generally, "a composer was defined in part by his or her relationship to Cage" (p. 300) after his arrival at Darmstadt in 1958. Iddon is careful to show, through his detailed deconstruction of the idea of the Darmstadt 'school,' that Cage did not disrupt an aesthetic order, but rather a social one - the idea of a school (p. 301).

This volume could also be read as an analysis of the role of music criticism in the perceived and objective (if this term can ever be appropriate in this context) aesthetic production of an art world. What we see here is the bi-directional nature of criticism: the judgments publicly provided by critics, be they composers themselves or not, influence production and vice versa, even, and perhaps especially, when these judgments are erroneous. One cannot analyze the development of new music without taking into account its often faulty reception by individuals invested with the authority to discuss it in public fora. This does not, however, amount to a plea for more capable critics. Instead, this is part and parcel of the evaluative and interpretive work necessary and inherent to art worlds, and the shifting sands of criticism are a reflection of the political climate (Adorno's reaction to the perceived totalitarianism of serialism cannot be read as divorced from the events he witnessed in his lifetime), the institutional climate (Darmstadt, as an identifiable institution, provided fertile ground for the formation of an aesthetic school), and the struggles of newcomers to find a place for themselves. We also see a shift in critical authority throughout this book: increasingly, the young composers present at Darmstadt are given the responsibility of providing the critical discourse on their own work and that of their peers. This fits into a larger phenomenon analyzed elsewhere, that of the rise of the composer-critic, or the artist as evaluator ${ }^{5}$.

11 Iddon is necessarily in dialogue throughout this book with Amy C. Beal, whose work is a reference point for new music scholars generally and scholars of cultural policy in post-war Europe ${ }^{6}$. He relies on her work for some of his historical narrative, all the while honing her conclusions with information from new archival work. The primary distinction one might draw between their work is one of perspective: Beal tells the tale of Darmstadt from an American point of view, whereas with Iddon we inhabit the German perspective. Their work can fruitfully be read together.

The conclusion to this volume is uncannily brief - Iddon concludes with a reflection on John Cage as a stranger, based on the theorization of this concept by Zygmunt Bauman ${ }^{7}$ (p. 300-303). These musings could very well have been developed further, and a sociologist would wish for the inclusion of Georg Simmel's work on the stranger ${ }^{8}$. But despite the distinctly sociological bent of this volume, it is not meant to be read as a treatise on the sociology of Darmstadt - its references remain resolutely musicological, notwithstanding the overt analysis of the social context. But one can only really conclude on a note of praise: not only is Iddon's prose a pleasure to read, but his analysis both of the works presented and the discourse surrounding them is deep, insightful, and detailed - for someone familiar with scholarship on Darmstadt and for musicologists, sociologists and anthropologists working on art worlds, or those interested in the sociology of criticism, social constructions of aesthetic hierarchies, or Adorno's role in new music after World War II. 


\section{NOTES}

1. ADORNO, Theodor W., "À propos du problème de l'analyse musicale", in BUCH, Esteban, DONIN, Nicolas and FENEYROU, Laurent (eds.), Du politique en analyse musicale, translated by Martin Kaltenecker, Paris, Vrin, coll. Musicologies, 2013, p. 31. This is from a lecture Adorno gave in 1969, wherein he refers to hearing Goeyvaert's Sonata for two pianos (18 years prior) at Darmstadt, but we must give credit where credit is due, as Adorno also recognized, in 1961, that his criticism of this work may have been misplaced (Adorno, cited by Iddon on p. 288-289).

2. For more information on the influence Eunice Katunda had on the work of Nono and Bruno Maderna, see, for example, the work of Michelle Agnes Magalhães, "The Katunda-Nono Correspondence (1949-1953): The Role of Eunice Katunda in Luigi Nono's Formation”, Project proposal, 2013, online : http://www.bv.fapesp.br/en/bolsas/138078/the-katunda-nonocorrespondence-1949-1953-the-role-of-eunice-katunda-in-luigi-nonos-formation/ [ accessed 20 February 2014], and for a review (in English) of recent scholarship in Portuguese on the subject, BÉHAGUE, Gerard, "Recent Studies of Brazilian Music: Review Essay", Latin American Music Review / Revista de Música Latinoamericana, Vol. 23, № 2, 2002, p. 235-251.

3. Iddon glosses over the important role played by Karl Amadeus Hartmann in the early years of Darmstadt, and in the new music scene generally in Germany after World War II. While it is of course impossible to conduct a detailed analysis of the role of every single actor present in this historical period, it is surprising to see how little ink Iddon devotes to the figure of Hartmann (see, for example, ROTH, Alexander, "Rethinking Postwar History: Munich's Musica Viva during the Karl Amadeus Hartmann Years (1945-1963)”, The Musical Quarterly, Vol.90, № 2, 2007, p. 230-274.).

4. See, for example BUCH, Esteban, DONIN, Nicolas and FENEYROU, Laurent (eds.), Du politique en analyse musicale, op. cit.

5. Reflections on the artist as critic can be found in work that approaches art worlds from radically different angles. See, for example, BECKER, Howard S., Art Worlds, Berkeley, University of California Press, 1982; BORN, Georgina, Rationalizing Culture: IRCAM, Boulez, and the Institutionalization of the Musical Avant-Garde. Berkeley, University of California Press, 1995; CRAIG, Ailsa, "Sustainability, Reciprocity and the Shared Good(s) of Poetry", Journal of Arts Management, Law and Society, Vol.37, №3, p. 257-269, 2007; FRANÇOIS, Pierre, CHARTRAIN, Valérie and WRIGHT, Stephen, "Les critiques d'art contemporain : Projet de recherche", Project proposal, La Délégation aux arts plastiques du Ministère de la culture, 2003, online : http:// pierrefrancois.wifeo.com/projets.php [accessed 10 February 2014]; MECKNA, Michael, "Copland, Sessions, and Modern Music: The Rise of the Composer-Critic in America", American Music, Vol. 3, № 2, p. 198-204, 1985; or MENGER, Pierre-Michel, Le paradoxe du musicien: le compositeur, le mélomane et l'État dans la société contemporaine, Paris, L'Harmattan, nouv. éd., coll. "Logiques Sociales", Série Musiques et Champ Social, 2001.

6. See, for example, BEAL, Amy C., "Negotiating Cultural Allies: American Music in Darmstadt, 1946-1956", Journal of the American Musicological Society, Vol. 53, No 1, p. 105-139; and BEAL, Amy C., New Music, New Allies: American Experimental Music in West Germany from the Zero Hour to Reunification, Berkeley, University of California Press, California Studies in Twentieth-Century Music 4, 2006.

7. BAUMANN, Zygmunt, Postmodernity and Its Discontents, Cambridge, UK, Polity Press, 1997.

8. This can be found in English in SIMMEL, Georg, The Sociology of Georg Simmel, Translated, edited and with an introduction by Kurt H. Wolff, New York, Free Press, 1964. 